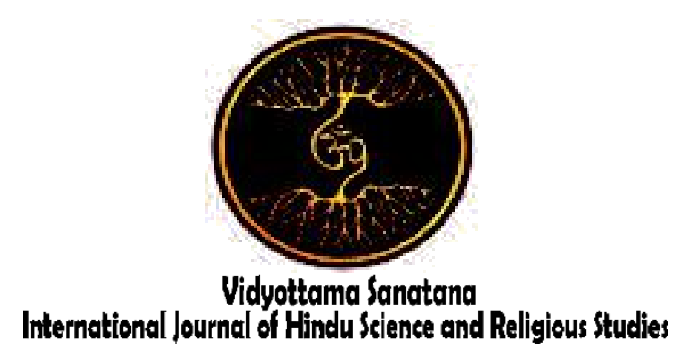

Vol. 5 No. 2 October 2021

\title{
RESOLUTION OF SOCIO-RELIGIOUS CONFLICT: REJECTION OF PIODALAN RITUAL IN MANGIR LOR, BANTUL
}

\author{
By: \\ Niyoko $^{1}$, Bani Sudardi ${ }^{2}$, Mahendra Wijaya ${ }^{3}$, Warto ${ }^{4}$ \\ $1,2,3,4$ Universitas Sebelas Maret, Surakarta, Indonesia. \\ E-mail: ${ }^{1}$ yokoniyoko@gmail.com
}

\begin{tabular}{|l|l|l|}
\hline Received: May 27, 2021 & Accepted: May 31, 2021 & Published: October 31, 2021
\end{tabular}

\begin{abstract}
Religion functions are to build brotherhood, yet religions can also be a source of conflict.The rejection of Piodalan Ritual carried out by Maha Lingga Padma Buwana Community by a number of Mangir Lor Sub-village residents, is a socio-religious conflict. The research aims to find out and explain why there is the rejection of Piodalan Ritual, and how the government together with the community resolve the conflict. The research uses a case study approach. Data collection techniques include interviews, observations, documentation, and triangulations. Primary data sources are from structural officials of government and cultural leaders of the community. Secondary data sources are from documents, reference books, and historical records. Analysis of qualitative data in interactive and continuous manners includes data reductions, data presentations, and conclusions. The result shows that the conflict between Mangir residents and Mahalingga Padma Buwana Community is the lack of communication and different perceptions regarding the Piodalan Ritual. The government and the community resolve the conflict by utilizing the local wisdom values, rembuk desa (deliberation), rukun (harmony), and ngajeni (respect).
\end{abstract}

Keywords: local wisdom; socio-religious conflict; piodalan ritual. 


\section{INTRODUCTION}

Conflicts are found in all aspects of social relations inter individual relationships, individual relationships within groups and group conflicts. There are two forms of conflict: collective and individual. Collective conflict occurs when conflicting parties consist of many people or groups, while individual conflicts are between individuals. Conflicts in society can be good because they encourage changes in society, but bad if they occur continuously without any solutions.

There are three views of conflict: bad and destructive, neutral (not good and not bad), good and necessary (Wirawan, 2013: 113-115). Bad and destructive conflicts are negative and have to be prevented according to the traditional point of view. They occur in many bureaucratic, feudalistic, and paternalistic social systems. Which always consider conflicts to be the results of violations of their norms. Human relation view neutral conflicts as natural occurrences and human phenomena that cannot be avoided. Humans are created with characters that are contradictory to one another with different perceptions and opinions which are the conflict source. If managed properly, conflicts will create something good and vice versa. Leaders and managers who assume that conflicts are neutral will have a high tolerance for conflicts. Their duties are to create conflict management mechanisms to prevente destructive conflicts and use them for social system development.

The interactionists view conflicts as good and necessary to create changes and progress of thesis, antithesis, and synthesis. Those who think conflicts are good and build something new will encourage leaders and managers to continue the ongoing conflict to a minimum, encouraging creativity and self-criticism. Conflicts are healthy part of a collaborative process to develop creativity and innovation for team members. Conflicts that occur are well managed and directed to be constructive conflicts to create organizational learnings.

This research departs from perpective that conflicts are neutral, depending on how to manage and control the conflicts. Thus, it is expected that management and control strategies, can be learned from this research. Furthermore, the results of this research can be used as a comparative study with other conflict case studies for increased knowledge on the methods taken in resolving conflicts.

Research on socio-religious conflict in Mangir has never been conducted. In general, the research is about literature studies and performing arts. Mangir subvillage is famous for the story of Ki Ageng Mangir Wonoboyo with all his attributes such as his powerful spear named Kyai Baru Klinting and his courage to oppose Panembahan Senopati, the Ruler of Mataram-Islam Kingdom I (1584-1601). Ki Ageng Mangir Wonoboyo is attracted to Pembayun, the daughter of Panembahan Senopati, whose story ends tragically in the death of Ki Ageng Mangir Wonoboyo (Balai Penelitian Bahasa Yogyakarta,1980). Many literature students and literary scholars become interested in conducting literary research related to this story.

One research is conducted by Setiawan (Setiawan, 2014). Konstruksi dan Perbandingan Cerita Rakyat Ki Ageng Mangir. It compares the reconstructed version of Ki Ageng Mangir folklore from two different regions: Pleret and Mangir, then compares them with Seymour Chatman's narrative structural theory about a narrative structure that composes two main topics: the story and the discourse. The results show that there is no difference between the folklore in Pleret and Mangir regions.

Another research entitled Kuasa Patriarki Dalam Drama Mangir Karya Pramoedya Ananta Toer is conducted by Fadli ( Fadli, 2016) It describes the form and factors supporting the power of patriarchy in the drama Mangir by 
Pramoedya Ananta Toer. It also describes the form of women's resistance to the power of patriarchal system and gender injustice that befell female characters by studying it using feminist literary criticism.

A research on the socio-religious conflict in Bantul Regency entitled Konflik Elit antara Muhammadiyah dan Gerakan Tarbiyah di Kecamatan Piyungan Kabupaten Bantul Daerah Istimewa Yogyakarta is conducted by Triwibowo (2008) It uses descriptive qualitative method to obtain a systematic description of the conflict about the affiliation of religious organizations. The conflict arises because of the dualism of membership, the spread of other ideas within Muhammadiyah, the exodus of Muhammadiyah cadres to the Tarbiyah Movement, and the existence of political activities under the guise of da'wah in Muhammadiyah. There is a strong resistance from Muhammadiyah elite to Tarbiyah Movement because they have to protect Muhammadiyah from political interests and maintain Muhammadiyah ideology.

The title of Raharjo's research (Raharjo 2008) is Konflik antara NU dan Muhammadiyah (1960-2002) di Wonokromo Pleret Bantul Yogyakarta. The conflict starts after Muhammadiyah comes to Wonokromo which is the base of NU (Nahdlatul Ulama). Muhammadiyah presence causes the originally homogeneous community becomes heterogeneous, resulting in the categorization of NU (Nahdlatul Ulama) and Muhammmadiyah leading to verbal and physical conflicts.

Researches on socio-religious conflicts generally analyze the conflict sources and the relations between conflicting actors. This research also examines the local wisdom which is useful in resolving conflicts and maintaining harmony between community members.

This research used a case study approach on a case that occurred on Tuesday, November 12, 2019, in Mangir
Lor Sub-village, Sendangsari Village, Pajangan, Bantul. At that time, the Piodalan Ritual was held at Utiek's house, a native of Mangir who originally embraced Islam and then converted to native beliefs and Hinduism. This ritual was followed by Maha Lingga Padma Buwana Community members. The purpose was for people's lives to be good and prosperous. It was a ritual to honor a god who lives in a temple.

When the ritual took place, a group of Mangir Lor residents opposed it because it did not get permission from the relevant agencies. They obstructed the guests arriving at Utiek's house, resulting in a dispute between the group of ritual actors and the group that opposed the ritual. The police, assisted by the army, came to the scene to secure the situation. After some negotiations mediated by the police, the ritual was stopped.

Due to this incident, a conflict between Mangir Lor residents and Utiek's community happened. Although this conflict is on a local scale, it should be noted that the various major conflicts occuring in Indonesia started as small disputes between individuals at the family and village level (Purwasito, 2015: 431)

Therefore, this research is based on the view that every dispute in society, both small and large scale, still needs to receive serious attention to obtain adequate knowledge and experience in resolving conflicts.

Based on this case the problems are formulated as follow:

1. Why does a group of Mangir Lor Sub-village residents reject the Piodalan Ritual?

2. How do the government and the community resolve the conflict that occurs in Mangir Lor Sub-village?

The research objectives are as follow:

1. To know and understand the background and reasons behind the Mangir Lor sub-village residents rejection toward the Piodalan Ritual. 
2. To know and understand the steps taken by the government and Mangir Lor sub-village community in resolving conflicts that occur in Mangir Lor.

\section{METHOD}

This research used a case study approach, which is a qualitative research approach that aims to describe a particular case using information from various sources (La Kahija, 2018). The data in this case study came from six sources: documents, archival records, interviews, direct observations, participant observations and physical artifacts (Yin, 2003: 83). To understand the phenomena, how and why questions were formulated (Yin, 1994: 21). The main research instrument was the researcher themselves (human instrument), and the second instrument is the activists in NGOs (NonGovernmental Organizations). Primary data and secondary data sources were selected purposively. The primary sources were conflicting parties, religious leaders, community leaders and officials. The secondary sources were documents, reference books, discussion notes, and village history. Data collection was conducted through in-depth interviews, observations, documentation and a triangulation. Data analysis was carried out by data reductions, data presentations and conclusions (Miles \& Huberman. 1994).

\section{RESULT AND DISCUSSION}

\subsection{Reasons for the Piodalan Ritual Rejection}

Causes of the conflict between the group of Mangir Lor residents and Utiek's group (Maha Lingga Padma Buwana Community) are lack of communication, differences in perceptions of the ritual, and lack of socialization from Utiek to the residents regarding the ritual. The conflict intensifies because each group holds firmly on its stance. Mangir group wants the ritual to be carried out after obtaining permission from the government. Meanwhile, Utiek's group believe that they should continue the ritual even though they did not have permission because it is a religious activity so a notification letter is enough.

On the day of the ritual, Tuesday, November 12, 2019, 50 guests were invited from Jakarta, Bali, North Sulawesi, Jambi, and West Java. The religious background of the guests were native beliefs, Buddhism, and Hinduism. The ritual was led by a Buddhist religious leader, Pendeta Padma Wiradarma and a Hindu religious leader, Pedanda Sri Begawan Gede Putra Manuaba, followed by Tarawangsa followers West Java, Kerinci Jambi, and Talaut North Sulawesi. The people's rejection was getting persistent, they shouted for the ritual to be stopped, the guests who arrived were blocked, cars were attacked, and the guests were prohibited from entering Mangir and asked to leave.

\subsection{Factors behind the Rejection of Piodalan Ritual \\ 3.2.1 Perception Factor}

The ritual rejection occurs because of perception differences. Perception is the experience of objects, events, or relations that are obtained by inferring information and interpreting messages. Interpreting the meaning of sensory information involves not only sensation, but also attention, expectation, motivation, and memory (Desiderato, 1976). Perception is influenced by functional factors that come from needs, past experiences, and personal factors. What determines perception is the characteristics of the person responding to the stimuli (Rakhmat,1994: 56). Perception the set of processes by which we recognize, organize, and make sense of the sensations we receive from environmental stimuli (Sterberg, 2012: 535).

The group that rejects the ritual was influenced by their past experiences and Islam religion that they followed. They see the ritual as an unclear religious ceremony because it is followed by various backgrounds of native beliefs and religions. Meanwhile, according to Hinduism, the 
participation of various beliefs and religions in the Piodalan ritual is possible because the character of Hinduism is open and flexible. Hinduism accepts all people with any cultural background or religion to attend Hindu religious ceremonies. It is called Istadevata, the manifestation of God in various forms, and Adhikara, which is universal, the same truth is found in diversity (Pudja, 2002).

Koentjaraningrat (1981) said that there has never been a society in this world that only adheres to one form of religion. Religious forms are elements that are always mixed in various religious activities, for example, a religion that is born monotheistic contains elements of animism, or polytheism. Therefore, religion is a complexity that contains various forms of religion (Haryanto et al , 2017)

Perception is also influenced by functional factors referred as frames of reference. In communication activities, it affects how people give meaning to the messages they receive (Rakhmat, 1994: 58). The group that rejects uses a frame of reference for the notion of Islam as the religion of revelation with an orderly and standard sharia and worship system so when they witness the ritual, perception arises that the ritual is an unclear mixed religious activity.

Perception is also influenced by structural factors. According to the Gestalt theory (Wertheimer, Koffka, Kohler), when we perceive something, we perceive it as a whole. We do not look at the pieces and then assemble them. The parts of the field that are separated are in dynamic interdependence (i.e. in interactions), and therefore determine the distribution of facts and their local qualities. If we want to understand an event, we must view them as a whole. To understand a person, we must see the context, the environment, and the problem (Sternberg, 2012).

In Piodalan ritual's case, there are several group structures: the group rejecting the ritual, the ritual practitioners'group, and Utiek's family.
The group that rejects the ritual and Utiek's family are actually one group, namely the residents of Mangir sub-village. However, Utiek, who converts from Islam to native beliefs and Hinduism, and her group that performs the Piodalan ritual, is included in another group, namely Piodalan ritual practitioners.

In terms of religion, Utiek is a Mangir descent like other Mangir residents, but no longer has the same religion because she has embraced a native belief and Hinduism. Thus, they have different perceptions due to differences in norms, values, and teachings causing the socio-religious conflict.

\subsubsection{Political Factor}

Citizens' freedom to express their religions is often faced with positive laws made by the country. In many cases, the positive law does not fully guarantee the freedom of religious expression of its citizens leading to religious-based social conflicts in a country. The example is Joint Regulation of the Minister of Religion and the Minister of Home Affairs No. 9 and No. 8 of 2006 concerning the Establishment of House of Worship (Ministry of Religion Affairs of the Republic of Indonesia "Peraturan Bersama Menteri Dalam Negeri dan Menteri Agama Nomor 9 Tahun 2006 Nomor 8 Tahun 2006).

Article 14 section 1 states that the establishment must meet the administrative and technical requirements of buildings. In section 2, the specific requirements are explained. First, there should be at least 90 ID cards legalized by local officials. Second, there should be at least 60 people authorized by the village head as the support of local community. Furthermore, there must be written recommendations from the head of the regency/city religious affairs department, and the regency/city of FKUB (Forum Kerukunan Umat Beragama - Forum for Religious Harmony). Minority groups adhering to certain religions will find it difficult to establish the house of worship because the 
joint regulations of the two ministries are difficult to fulfill.

There are three elements causing the conflict in Piodalan ritual rejection: discrepancy, behavior, and feelings. The discrepancy in goals and values occur because the group that rejects is Muslim and the other group is adherents of the native belief and Hinduism. Diversity due to different belief backgrounds does not always cause conflicts. However, in this case, the group that rejects the ritual by obtaining supports from the government tries to control the group that does the ritual by questioning the permit and place for worship.

For the government, control efforts are understood as a government function in terms of services and arrangements so that people's lives can run well, orderly, and dynamically. This is in line with Dahrendorf's conflict theory stating that society is united by "imposed restrictions". Thus, some positions in society are power and authority delegated to others. The government function to maintain order and control the community is opposed by the way the Piodalan group continues to carry out the ritual despite the absent of permit.

The control of intergroup conflicts carried out by the government is based on regulations for houses of worship and worship activities stated in the Joint Regulation of the Minister of Religion and the Minister of Home Affairs No. 9 and No. 8 of 2006 concerning the Establishment of Houses of Worship. The understanding of structural officials and the group who rejects the ritual is that the pura built by Utiek is a house of worship so that it must have a permit. The issue of the need for permission from structural officials in carrying out the ritual is in line with Dahrendorf's theory stating that power and authority always place individuals at the top and bottom positions in every structure. Because the authority is valid, every individual who does not submit to the existing authority will be subject to sanctions (Ritzer, 2018: 26).
In this case, Utiek's group is sanctioned for not being permitted to carry out the ritual. The issue of permission is also related to regulations from HPK (Himpunan Penghayat Kepercayaan Association of Native-Belief Followers), which has now changed its name to MLKI (Majelis Luhur Kepercayaan Terhadap Tuhan Yang Maha Esa Indonesia organization of adherents of local religions and indigenous beliefs Indonesia). Membership in HPK can be followed individually or in groups with any religious background. Whereas in MLKI, membership must be in the form of an organization, legal entity, have a Memorandum of Association/Articles of Association, registered with the Ministry of Education and Culture and the Attorney General's Office, and have a scripture. As individuals cannot become a member of MLKI. Utiek cannot fulfill such membership requirements. As a result, she also has difficulty obtaining permission from the government.

\subsubsection{Conversion Factor}

The Latin word of changing religion is "conversio" in the English word is "conversion". Those words have a broader meaning: to turn, repent, change, join a monastery. According to Max Heirich, there are four factors encouraging people to convert (Hendropuspito,1983: 78-82).

(1) According to theologians, religious conversion is due to divine influence. A person or group joins or converts to a religion because they are motivated by God's grace. Without the special influence of God, one cannot accept a belief that is radical in nature beyond human power. Divine influence is beyond social observation so it does not become the competence of social science.

(2) According to psychologists, religious conversion is due to liberation from mental pressure arising because of the social 
environment influence. People look for a way out by looking for other strengths, namely joining a religion. A person gets a new perspective that can defeat previous motives or life standards that have been adhered to. The mental pressure arises from the following factors: family problems before converting such as problems with family members, arguments, sexual problems or mental loneliness creating psychological pressure. There is also a stressful environmental condition causing personal problems. Wilson (1973) adds that people feel excluded from their group and then live alone, the group is torn apart, a drastic change in one's status, a divorce that causes a person to become a widow, a marriage with someone who has different religion, and other sources of pressure such as birth order and poverty factors.

(3) According to education experts, religious conversion is due to educational situations (socialization). The education system through schooling can be justified, including the driving factor for joining or converting to a religion. However, the reality shows that only a small proportion of students from the religious-based schools convert to the religion of the school founders.

(4) According to social experts, religious conversion is due to various social influences such as the influence of interpersonal relationships, not only religiously oriented but also in the profane fields (science, culture, etc.). These variables are persuasive, such as: invited to join a group by a close friend; invited to repeatedly attend services of a religious ceremony; encouraged by relatives or closest friends while "looking for a new purposes"; develop good relations with certain religious leaders before "repenting". Also, there is a coercive conversion effect. Coercion can be moral and physical. The history of the development of religions records the fact of moral compulsion. In the Middle Ages, there is a saying that reads: "Cuius regio illius est religio", which means people who live in the territory of a king are obliged to embrace the religion of the king. At the time of Majapahit kingdom, there is also a saying "agama ageming ratu" (religion of the king).

This Piodalan ritual case is inseparable from Utiek's background converting from Islam to a native belief and Hinduism. She is a native of Mangir the youngest with 9 siblings. Her extended family is Muslim, and all her siblings have had Hajj (Interview with Utiek and Nusya, Saturday, December 14, 2019). After graduating from high school, Utiek left Mangir and lived in Bandung. In 1998, the 35-year-old Utiek returned to Mangir with her only son who was in kindergarten age and became a single parent. She was 56 years old when the ritual incident happened. Her son graduated with a bachelor of pharmacy degree and is currently pursuing a professional degre at Sanata Dharma University.

Based on the several factors stated above, theological factors could be the cause of Utiek's conversion to a new religion. Utiek repeatedly said that she got wangsit (mystical messages) while doing meditation. This wangsit is understood as guidance from the ancestors so that she takes care of the ancestral heritage, Hinduism. When members of the community gathered at Mangir, they felt that it was a miracle because they got the same wangsit of houses, places, roads, pura, and ritual while they have never met each other before. They believed it as ancestral guidance that moves people who 
have the same heredity from the same ancestor to awaken and maintain Hinduism as an ancestral belief in Mangir. These events were then imbued and believed as "supernatural" experiences.

There are social and theological factors that influence the conversion because before and after the conversion, Utiek meet religious people and leaders of the native belief and Hinduism. That is the reason why she joined and carried out the spiritual activities. In the new place and environment, Utiek found a happy place and acceptance. "Nah yo iki, kene, kene, ayo sinau bareng, belajar..." ("Well yes, come here, let's learn together...") were the soothing words of Utiek's spiritual teacher. Utiek often said that she was not looking for ther teacher but the teacher found her. All their stories about wangsit encouraged them to gather.

The psychological factor could be the cause regarding Utiek's status as a single parent. Not every single parent is bound to experience stress. However, it does not rule out the possibility that a single parent feels mental pressure because one faces a tough life struggle that puts psychological, social, and economic pressure. A widow with children without a husband is sometimes still considered bad by society. If someone who is experiencing mental pressure finds people or groups that provide inner peace, then the old religion is abandoned.

The restlessness of Utiek's spiritual life is reflected in her mixed spiritual activities. This is also expressed by the Mangir residents, "kuwi ki jane melakukan agama opo ta" ("what kind of religious practice is she doing?"). Utiek creates a community, builds a pura with phallus-yoni in her open yard, and holds rituals followed by various native beliefs, Hinduism and Buddhism. As a person who is new in a native mixed belief living in Mangir where ninety-nine percent are Muslim and less supportive, Utiek religion's obscurity is very obvious.

Besides that, in Central Mangir the term Pura Dalem is only used by Utiek and her community. Mangir residents use the term candi (temple) instead. They think that their ancestors' legacy is the legacy of $\mathrm{Ki}$ Ageng Mangir Wonoboyo with Watu Gilang (stone throne) and Langgar (Muslim prayer rooms), not the one with the temple. The pura layout is also inaccurate. In an orderly village with a majority of Hindu residents, Pura Dalem is located in Kelod-Barat (southwest), while in Mangir it is located in the middle. The temple in Utiek's place is called Pura Puseh that is supposed to be located in kaja-Timur (northeast), but it is in the north instead. Then, Pura Bale Agung is supposed to be located in the middle of the village, but in Mangir there is no Pura Bale Agung. The three temples have their respective functions (Hadiwijono, 1975: 114). The incorrect location of pura in Mangir makes it difficult to fulfill the correct conditions regarding the establishment of pura. It shows how unclear the spiritual activities and facilities that are carried out by Utiek with her group.

\subsection{How Government and Community Resolve Conflict}

At first, both parties tried to resolve it by themselves but there was no solutions. Then they used a third party as a mediator. Mangir group reported to Pajangan Sectoral Police, while Utiek's group was accompanied by the non-governmental organization, Gemayomi (Gerakan Masyarakat Yogyakarta Melawan Intoleransi - Yogyakarta Community Movement against Intolerance).

On Monday night, November 11, 2019, those in conflict negotiated Pajangan Sectoral Police, but no agreement was reached. Mangir group still needed a permit for Piodalan. On Tuesday, November 12, 2019, when the ritual was carried out, the rejection happened.

On Monday, November 18, 2019, the Regent of Bantul, Surhasono, together with Forkompimda (Forum Komunikasi Pimpinan Daerah - Regional Leadership Communication Forum) took the initiative 
to mediate those in conflict. At the regent's office, deliberations were held involving government officials, conflicting parties, Gemayomi NGO, and Mangir community leaders. It was revealed that the problem arose because of lack of communication, lack of socialization about Piodalan to the local residents, and the unclear status of Utiek's religion.

In the meeting, it was clear that Piodalan Ritual was a Hindu religious ceremony. Utiek declared herself a legal Hindu. The ritual did not need permission because it was a religious activity. PHDI (Parisada Hindu Dharma Indonesia Indonesia Hinduism Society) Yogyakarta would guide Utiek if a religious ceremony would be carried out. Muhammad Irwan Susanto, Head of Sendangsari Village, asked Utiek to coordinate with the local residents if she held an event involving many people so that the local residents did not reject the event. The Regent of Bantul would facilitate if the Hindu community in Bantul wanted to build a Pura (religious temple) (Hasanudin, 2019).

The deliberation at Bantul Regent's office resulted in an agreement to hold a declaration of harmony among Mangir community. On Wednesday evening, December 11, 2019, about two hundred Mangir residents held the declaration under the name "Declaration of Harmony for Mangir Community, Sendangsari Village, Pajangan District, Bantul Regency". The event was held at Ndalem Saryantan, which was located in a confluence of Progo River and Bedog River, as a spiritual and cultural tourism area in Sendangsari Village (Daruwaskita, 2019).

The Mangir community declaration was led by Sendangsari Village Head, Muhammad Irwan Susanto and attended by a member of Commission X of The House of Representatives of Republic Indonesia, MY Esti Wijayati who was involved in resolving the conflict. She funded the event using aspiration fund. The declaration was also attended by representatives of Bantul Departmental Police, Pajangan Sectoral
Police, Pajangan Military District Command Sector, administrators of Indonesia Hinduism Society, and Regional Office of the Ministry of Religion. In the declaration, the community of Mangir Lor, Mangir Tengah, and Mangir Kidul subvillages stated the followings:

1. Always be loyal and uphold the Unitary State of Republic Indonesia that is based on Pancasila and the 1945 Constitution.

2. Always maintain harmony and work together to protect the nation from radicalism that is contrary to the principles of unity in Indonesia, Bhineka TunggalIka (Unity in Diversity).

3. Eager to support the government of Sendangsari Village to create a conducive atmosphere in the three Mangir sub-villages and their surroundings to create peace and realize development in all fields for the common welfare.

4. Together with all stakeholders make Mangir area and their surroundings into a tourism and cultural area that is rich in the history of Ki Ageng Mangir, natural potential, and traditional cultural arts.

5. Be ready with all Mangir community to protect, guard,

maintain, and implement the specialty of Special Region of Yogyakarta for Indonesia.

\subsubsection{Utilization of Local Wisdom}

Culture is a vehicle and discourse for people to continually adjust to changes, whether caused from within or outside their culture without having to lose their cultural identity. Such societal adaptation is a process of becoming knowledgeable community members to maintain their lives. The ability to maintain cultural practice is known as tradition (Ministry of Culture and Tourism of the Republic of Indonesia, 2011). 
Tradition means traditum, everything that is passed down, from the past to the present, in the form of behavior patterns including beliefs, rules, and prohibitions, to re-run behavior patterns that are constantly changing. In practice, the tradition takes the form of an activity carried out repeatedly in an attempt to reinforce patterns of behavior that rely on norms for future actions. The form of tradition is the activities on life cycle, natural environment, and social environment which are then interpreted as local wisdom.

Etymologically, local wisdom is local ideas that are wise, valuable, and followed by members of the community. Meanwhile, according to anthropological concept, local wisdom is called indigenous or local knowledge, or local genius, which is the basis of cultural identity.

The notion of local wisdom is a creative response to local situational, geographic-political, and historical situations that contain attitudes, views, and abilities of a community in managing its spiritual and physical environment. This is an effort to be able to provide endurance and growth power to members of the community in the area where the community is located.

Therefore, local wisdom is a form of endurance and growth power manifested through a view of life, knowledge, and various life strategies in the form of activities carried out by local communities. This is useful for answering various problems in fulfilling their daily needs, as well as preserving their culture. It is in that sense that local wisdom is the answer to maintaining and continuously growing the culture it supports.

Every society, including traditional society, in the context of local wisdom, has a process to become intelligent and knowledgeable. This is related to the desire of community members to be able to maintain their lives. Therefore, community members spontaneously think of ways to do and create something that is needed in processing natural resources to ensure the sustainability and availability of natural resources without disturbing the balance of nature. Through this process, a very valuable discovery can happen. Every member of the community can collect all this information preserve and pass it down from generation to generation as an effort to maintain their lives.

In line with cultural changes that occur in people's lives, people also slowly develop the knowledge that has been passed down and then create methods for building knowledge. Basically, knowledge creation is indigenous ways or technologies to utilize natural resources for the continuity of people's lives. Therefore, the community develops an indigenous knowledge and technology system, local wisdom, which includes various ways to deal with life, such as health, food, food processing, and soil conservation.

Such local wisdom generally takes the form of an oral tradition and is mostly developed in rural areas because of the need to experience, maintain, and live in accordance with the situation, conditions, abilities, and values that are imbued with the community. Therefore, local knowledge becomes part of their wise way of life to solve all the problems so that people can continue their lives.

\subsubsection{Javanese Islam (Islam Kejawen) is Local Wisdom}

Mixing or the meeting between two or more cultures and religions which influences one another often occurs in Indonesia. When viewed from the relation between Islam and culture, there are two things that need to be explained: Islam as a socio-cultural conception and Islam as a cultural reality. Islam as a socio-cultural conception by experts is often referred to as the great tradition, while Islam as a cultural reality is called the local tradition or also Islamicate, fields that are "Islamic" influenced by Islam (Bauto, 2014).

The great traditions of Islam are original Islamic doctrines that stick strictly 
to basic teachings. In a smaller area, this doctrine is covered in the conception of faith and sharia or Islamic law which inspires the mindset and action patterns of Muslims. These traditions are often referred to as centers as contrasted with feri-feri.

The small tradition is a realm of Islam influence (great tradition). This local tradition includes elements contained in the meaning of culture such as concepts or norms, human activities and actions in the form of works produced by the community.The process of acculturation between Islam and local culture then gave birth to local genius, the ability to absorb while selecting and actively processing the influence of foreign cultures so that a new unique creation that is not found in the territory of the nation can be achieved.

Local genius has these characteristics: able to survive against outside cultures; to accommodate elements of outside culture; able to integrate elements of outside culture into the native culture, and able to control and provide direction for further cultural development. As a norm, rule, and all activities of Indonesian society, Islamic teachings have become a model for society. It is in this context that Islam as a religion has become the culture of Indonesian society. On the other hand, local cultures that exist in the community do not automatically disappear with the presence of Islam. Some of these local cultures continue to develop by adopting Islamic colors. This development then gave birth to cultural acculturation between local culture and Islam.

Javanese Islam (Islam Kejawen) is an acculturation of Javanese culture with Islam. In socio-cultural terms, Islam Kejawen is a sub-culture and part of Javanese culture. Javanese culture itself includes sub-cultures that exist in Java, such as Pesisiran (north coast of Java), Banyumasan (Banyumas), and Nagari Agung (Yogyakarta Sultanate and Surakarta Sunanate) cultures. The term tanah Jawa (Javanese land) is used to not mention the island of Java because there are cultures that are not included in Javanese sub-culture such as Sundanese (West Java) and Betawi (Jakarta) cultures. The term Kejawen is used by the community to refer to the culture and traditions in the former Islamic Mataram kingdom, both in Yogyakarta (Sultanate and Pakualaman) and Surakarta (Sunanate and Mangkunegaran) (Bakri, 2016).

From these two areas, Kejawen (Javanism) tradition develops. The term Islam is used in Kejawen tradition as a separate identity that is different from Islamic puritanism identity and Javanese identity. Islam Kejawen is an Islamic religion that has adapted to the culture and traditions of Nagari Agung which can create an identity that combines Javanese and Islamic cultures into Islamic religiosity with Javanese colors. Kejawen Islamic culture is a form of syncretism between the holy word and local culture so that Islam Kejawen is a form of a religious phenomenon that is full of religious traditions with mystical characteristics. The mystical color of Islam in the Kejawen Islamic culture is so thick in the phenomenon of Javanese diversity. This cannot be separated from the role of Wali (severed saints of Islam in Indonesia) of Demak era and afterward in spreading Islamic da'wah culturally.

Hinduism, Buddhism, and animismdynamism beliefs are acculturated with Islam in their development. Examples of terms of kejawen faith are Hyang Maha Agung (Allahu Akbar / God is the greatest), Gusti Kang Murbeng Dumadi (al-Khaliq / The Creator), sedekah (shadaqah / alms), selametan (salamah / expression of gratitude to God by making a banquet). Islam teaches worship in a ritual dimension as a form of the Pillars of Islam explanation (The Profession of Faith - The Shahada, Daily Prayers - Salat, Alms-Giving - Zakat, Fasting - Saum, Pilgrimage to Mecca Hajj), and Pillars of Faith (belief in His angels, His books, His prophets and messengers, the Day of Judgment, doom \& divine decree) in Javanese life. Ritual 
worship include Kenduren/selametan tradition; Tingkeban/mitoni ceremony; Birth ceremony (nyepasar, akekah); Circumcision ceremony (ngeslamake); Marriage ceremony (ijab kobul, ngunduh manten, nduwe gawe); Death ceremonies (mitung dino, matang puluh, nyatus, nyewu, mendhak); Big days ceremony (suranan, saparan, ruwahan, muludan, syawalan).

In the shadow puppet show, it can be seen how Wali is capable of the acculturation of culture and religion. For example, Puntadewa has Kalimasada Jimat. The word Jimat Kalimasada is a Javanese accent from the Arabic word azimat and Kalimah syahadah. Janaka is followed by his servants called panakawan : Semar, Nala Gareng, Petruk, Bagong. These names have philosophical meanings. Semar is Arabic word Sammir which means to hurry up, Nala Gareng is from Nala Khairin which means to gain goodness, Petruk is from Fatruk which means to leave, Bagong is from al-Bagha which means badness. When combined, sammirnalakhairinfatrukilbagha means: hurry up to gain goodness, leave the badness. This is the path to heaven in Arabic jannah, being janoko in Javanese (Kangsalim, 2015).

Mangir is a sub-village that is so strong in caring for the traditions of their ancestors. The traditions they practice are a form of local wisdom, for example ceremonies related to the life cycle (birth, marriage, death). During pregnancy there are ngapati, mitoni ceremonies; after birth there are brokohan, sepasaran, puputan, selapanan ceremonies; and for death there are telung dina, pitung dina, matangpuluh, nyatus, nyewu. There are ceremonies related to important events or meanings in certain months such as suronan, muludan, syawalan, ruwahan, merti dusun, kendurenan, jamasan pusaka, jamasan watu gilang and art activities such as salawatan, dhibaan, hadroh, macapatan, jathilan, tayuban, kethoprak.

The Javanese Islamic tradition that is cared for and carried out by the Mangir community has resulted in inter-community harmony according to their respective status. The religious emotions, religious systems, religious ceremonies and religious communities produce unity in society.

\subsubsection{Javanese Community View of Life}

Regarding the local wisdom of the Javanese people about a safe and peaceful life, there are two basic principles according to Geertz (1961): rukun (harmony) and hormat (respect) (Wirawan, 2013). Rukun in Javanese culture means living in harmony and serenity. To create harmony, members of the community must keep away from everything that can interfere with harmony. Wilner (1970) states that the principle of harmony is the principle to avoid conflict. One that disturbs harmony and balance in life is conflict. The Javanese philosophical assumption regarding conflict is the traditional point of view: conflict destroys the harmony of life. Conflict goes against noble values and causes people to be unhappy. Therefore, according to Javanese culture, conflict should be avoided.

Meanwhile, the principle of respect means that everyone must respect each other according to their respective status. According to Javanese culture, humans are created unequal in a hierarchy of status. For example, the relationship status between men and women, husband and wife, children and parents, leaders and followers, laypeople and scientists, scholars and their followers, and so on. The status of nobility or priyai is not the same as that of commoners and cannot be exchanged with one another.

The Javanese people must respect the status so there will be harmonious social relations. Mulder (1978) describes a state of harmony as a condition in which all members of society live in harmony, peace without conflict, and help each other. Harmonious social relations lead to gotong royong (communal work) and the achievement of tata tentrem karta raharja (orderly, peaceful, prosperous). 
In Mangir case, there is a conflict between groups. When those in conflict have the initiative to resolve it themselves (self-regulation) by deliberation (rembukan / discussion), this is a sign that they have a desire to get along and make peace (islah), even though the result is a win-lose solution. Furthermore, because those in conflict are unable to resolve it on their own, conflict resolution involves a third party intervention as a mediator, namely the government, the Gemayomi NonGovernmental Organization (Yogyakarta Community Movement against Intolerance), community, and religious leaders.

When those in conflict have a willingness to reconcile, it is an indication that they respect government leaders, community leaders, and non-governmental organizations who want to help resolve their disputes. Respecting the status of leaders and community leaders in carrying out their functions, both leaders in government and leaders in society is a manifestation of the principle of respect in Javanese culture which is useful for maintaining harmony and conformity in life together.

Likewise, the declaration of harmony among Mangir residents followed by two hundred residents from Mangir Lor, Mangir Tengah, and Mangir Kidul is attended by the conflicting parties and officials such as the Head of the Village, Sub-village, District, Regency, Police, Military District Command Sector, religious leaders, community leaders, and House of Representative officials, in Ndalem Saryantan, Mangir Kidul. Their willingness to be present in the declaration also shows the willingness of the community to live together in harmony. Meanwhile, their willingness to attend the declaration of harmony initiated by leaders, community leaders, and religious leaders shows a respectful attitude towards the leaders.

\section{CONCLUSION}

The factors that influence a group of people to reject the religious rituals of other groups are: a) differences in perceptions of religious rituals between groups; b) political factors in the form of state policies that do not fulfill a sense of justice for one of the groups in carrying out its religious rituals; c) a person's conversion from the religion embraced in the previous group to another religion, causing the group's rejection of the person who converted as well as to the religion they embraced.

In resolving conflicts, the goverment and Javanese people make use of local wisdom, namely deliberation based on Islamic values that are integrated into Javanese culture, and the Javanese philosophy of living in harmony and respect. Deliberation or as-shulhu (al-islah) which means peace is an adequate way to resolve socio-religious conflicts. In deliberation, there is a process of mutual understanding and acceptance of the differences that exist between them. Thus, there is a positive influence of local wisdom on the resolution of socio-religious conflicts and the maintenance of harmony between community members.

\section{REFERENCES}

Bakri, Syamsul. (2016 Februari 24). Islam Kejawen (Agama dalam Kesejarahan Kultur Lokal). Accessed 2020 April 24. https://iain-surakarta.ac.id.

Balai Penelitian Bahasa Yogyakarta. (1980). Babad Mangir 1 dan 2. Proyek Penerbitan Buku Sastra Indonesia dan Daerah. Jakarta: Departemen Pendidikan dan Kebudayaan.

Bauto, Laode Monto. (2014). Perpektif Agama dan Kebudayaan dalam Kehidupan Masyarakat Indonesia (Suatu Tinjauan Sosiologi Agama), Jurnal Pendidikan Ilmu Sosial, 23 (1),11-31. 
Daruwaskita. (2019 Desember 12 ). Buntut Manis Kasus Mangir. Accessed 2020 Juli 31. https://jogja.idntimes.com.

Desiderato O. et al. (1976). Investigating Behavior: Prinsiples of Psychology. New York: Harper \& Row Publishers.

Fadli, Ibnul. (2016). Kuasa Patriarki dalam Drama Mangir Karya Pramoedya Ananta Toer. Thesis, Universitas Negeri Yogyakarta. Accessed 2021 Juli 27. https://eprints.uny.ac.id/37929.

Hadiwijono, Harun. (1975). Agama Hindu dan Buddha. Jakarta: BPK Gunung Mulia.

Haryanto et.al. (2017). Sistem Sosial Budaya Indonesia. Tangerang: Universitas Terbuka.

Hasanudin, Ujang. (2019 November 18). Warga Beribadah di Bantul Dibubarkan. Accessed 2020

Oktober 10. jogjapolitan.harian jogja.com.

Hendropuspito,O.C., D. (1983). Sosiologi Agama. Yogyakarta: Yayasan Kanisius.

Kangsalim. (2015).

Samminalakhairinfatrukilbagha Mantra Menuju Sorga. Accessed 20 Juni 2020.

https://www.kompasiana.com

Kementerian Agama Republik Indonesia. Peraturan Bersama Menteri Dalam Negeri dan Menteri Agama Nomor: 9 Tahun 2006; Nomor: 8 Tahun 2006. Accessed 2020 November 14. ntt.kemenag.go.id>dokumen.

Kementerian Kebudayaan dan Pariwisata Republik Indonesia. (2011). Kearifan Lokal di Tengah Modernisasi. Jakarta: Pusat Penelitian dan Pengembangan Kebudayaan. Accessed 2021 Juli 27.

http://repositori.kemdikbud.go.id/1 $3000 /$.
Koentjaraningrat. (1981). Beberapa Pokok Antropologi Sosial. Jakarta: Dian Rakyat.

La Kahija, Y.F. (2018). Penelitian Fenomenologis. Yogyakarta: PT Kanisius.

Miles, Matthew B. \& Huberman Michael A. (1994). Qualitative Data Analysis. Second Editon. London. New Delhi: Sage Publications Thousand Oaks.

Mulder, N. (1978). Mysticism and everyday life in contemporary Java: Cultural persistence and change. Singapore: Singapore University Press.

Pudja, Ida Bagus. (2002). Pendidikan Agama Hindu untuk Perguruan Tinggi Umum. Yogyakarta: UNY Press.

Purwasito, Andrik. (2015). Komunikasi Multikultural. Yogyakarta: Pustaka Pelajar.

Raharjo, Shoddiq. (2008). Konflik antara NU dan Muhammadiyah (19602002) (Studi Kasus di Wonokromo Pleret Bantul Yogyakarta). Thesis, UIN Sunan Kalijaga Yogyakarta. Accessed 2021 Juli27.http://digilib.uin.suka.ac.id> .

Rakhmat, Jalaludin. (1994). Psikologi Komunikasi. Bandung: Remaja Rosdakarya.

Ritzer, George.(2018). Sosiologi Ilmu Pengetahuan Berparadigma Ganda. (Alimandan Penerjemah). Kota Depok: Rajawali Pers.

Setiawan, Dhanu. (2014). Konstruksi dan Perbandingan Cerita Rakyat $\mathrm{Ki}$ Ageng Mangir. Thesis, Universitas Gadjah Mada Yogyakarta. Accessed 2021 Juli 27. http://etd.repository.ugm.ac.id/pene litian/detail/72179.

Sternberg Robert J. and Sternberg Karin. (2012. 2009). Cognitive Psychology. Sixth Edition. 20 Davis Drive Belmont, CA94002-3098 USA: Wadsworth Cengage Learning. 
Triwibowo, Iskam. (2008). Konflik Elit antara Muhammadiyah dan Gerakan Tarbiyah di Kecamatan Piyungan Kabupaten Bantul Daerah Istimewa Yogyakarta. Thesis, UIN Sunan Kalijaga Yogyakarta. Accessed $2021 \quad$ Juli 27.http://digilib.uinsuka.ac.id/id/id/ eprint/997/.

Wirawan. (2013). Konflik dan Manajemen Konflik: Teori, Aplikasi, dan Peneltian. Jakarta: Salemba Humanika.

Yin, Robert K. (1994). Case Study Research. London: Thousand Oaks. New Delhi: Sage Publication.

Yin, Robert K. (2003). Case Study Research: Design and method (3 ${ }^{\text {rd }}$ ed.). London: Thousand Oaks, CA: Sage. 